\title{
A COMPARISON OF PITUITARY LH LEVELS DURING DELAYED IMPLANTATION PERIODS INDUCED BY SUCKLING, PROVERA OR PROGESTERONE TREATMENT
}

\author{
ANANT P. LABHSETWAR* \\ Department of Anatomy, Washington University School of Medicine, \\ St. Louis, Missouri, U.S.A.
}

(Received 30th fuly 1968)

\begin{abstract}
Summary. Pituitary LH content was compared in pregnant rats in which implantation of blastocysts was successfully delayed for 9 to 12 days by three different methods. Both the concentration $(\mu \mathrm{g} / \mathrm{mg})$ and total content $(\mu \mathrm{g} / \mathrm{gland})$ of LH were low during lactational and Proverainduced delayed implantation periods but were high in bilaterallyspayed progesterone-treated rats when compared to cyclic control animals.
\end{abstract}

Delayed implantation of blastocysts in the rat can be induced by several procedures (Enders, 1967). The exact mode by which different procedures produce delay is uncertain but it is generally thought that they act on the pituitary either directly, or indirectly through the hypothalamus, to reduce the LH output and consequently to lower the level of oestrogen secretion by the ovaries (see review by Enders, 1967). This hypothesis appears attractive because exogenous oestrogen (Cochrane \& Meyer, 1957) or LH (Macdonald \& Armstrong, 1965) administration can overcome the experimentally induced delay of implantation. Therefore pituitary $\mathrm{LH}$ levels were compared during delayed implantation periods induced by various procedures.

Adult female rats ( 3 to 4 months old) of the Holtzman strain were maintained under standardized conditions including 14-hr artificial illumination daily (Labhsetwar, 1969). They were individually caged with males and the first day on which spermatozoa were found in the vaginal smear was taken as Day 1 of pregnancy.

Delayed implantation of blastocysts was induced by the following three procedures: (1) Lactational delay: post partum-mated animals were permitted to suckle an average litter of ten young (range nine to eleven) and killed 10 to 12 days post coitum. (2) Provera delay: a dose of $2 \mathrm{mg}$ of Depo-Provera (17 $\alpha$ acetoxy- $6 \alpha$-methyl progesterone, Upjohn) was injected subcutaneously for 9 to 11 days as described by Barnes \& Meyer (1964) beginning on Day 1 of pregnancy. (3) Bilateral ovariectomy + progesterone delay: rats were bilaterally spayed between 08.00 and 11.30 hours on Day 3 of pregnancy and injected daily with $4 \mathrm{mg}$ progesterone $(0.2 \mathrm{ml}$ corn oil, subcutaneously) for 9 or 10 days, following the procedure of Cochrane \& Meyer (1957).

* Present address : Biological Research Department, Pharmaceuticals Division, ICI, Alderley Park, Cheshire. 
On the day following the duration of the experimental period the rats were killed by ether (Labhsetwar, 1969). The uterine horns were flushed with normal saline and the presence or absence of blastocysts determined. Rats without blastocysts were rejected.

The anterior pituitary glands were bio-assayed for $\mathbf{L H}$ by employing a recent modification by Bogdanove \& Gay (1967) of the ovarian ascorbic acid depletion (OAAD) method of Parlow (1961). The details of the method have been described elsewhere (Labhsetwar, 1969). A four-point symmetrical assay design with two doses of standard and two doses of pituitary tissue from each group with four assay rats/dose was used. The dosages of pituitary tissue were selected on the basis of earlier experience and data in the literature so that responses of test preparations would fall in the range of the reference standard. The assay data were analysed by standard statistical procedures for parallel line assays described earlier (Labhsetwar, 1969). The mean index of precision was $0 \cdot 259$.

TABLE 1

PITUITARY LH LEVELS DURING DELAYED IMPLANTATION PERIODS INDUCED BY VARIOUS PROCEDURES IN THE RAT

\begin{tabular}{|c|c|c|c|c|}
\hline & $\begin{array}{l}\text { Cyclic } \\
\text { control }\end{array}$ & $\begin{array}{c}\text { Lactational } \\
\text { delay }\end{array}$ & $\begin{array}{c}\text { Provera }^{\mathrm{d}} \\
\quad \text { delay }\end{array}$ & $\begin{array}{c}\text { Bilateral spaying } \\
+ \text { progesterone } \\
\text { delay }^{\mathrm{e}}\end{array}$ \\
\hline $\begin{array}{l}\text { No. animals } \\
\text { Pituitary wt }(\mathrm{mg}) \\
\mathrm{LH}^{\mathrm{a}} \text { conc. }(\mu \mathrm{g} / \mathrm{mg}) \\
95^{\circ} \% \text { confidence limits } \\
\mathrm{LH} \text { content ( } \mu \text { g/gland) }\end{array}$ & $\begin{array}{c}6 \\
12 \cdot 4 \pm 0 \cdot 6^{b} \\
0 \cdot 83 \\
(0 \cdot 50-1 \cdot 39)^{\mathrm{g}} \\
10.32\end{array}$ & $\begin{array}{c}5 \\
10 \cdot 9 \pm 0 \cdot 1 \\
0 \cdot 26 \\
(0 \cdot 13-0 \cdot 51) \\
2 \cdot 83\end{array}$ & $\begin{array}{c}8 \\
8 \cdot 1 \pm 0 \cdot 4 \\
0 \cdot 21 \\
(0 \cdot 11-0 \cdot 42) \\
1 \cdot 74\end{array}$ & $\begin{array}{c}3 \\
10 \cdot 2 \pm 0 \cdot 2 \\
4 \cdot 81 \\
(2 \cdot 64-8 \cdot 75) \\
48 \cdot 9\end{array}$ \\
\hline
\end{tabular}

a equivalents of NIH-LH-s-12/mg wet pituitary.

bean \pm S.E.

- Mean number of young suckled was ten (range nine to eleven) and mothers killed on 10 to 12 days post coitum.

d $2 \mathrm{mg} /$ day from Day 1 of pregnancy for 9 to 11 days.

- $4 \mathrm{mg} /$ day from Day 3 (day of bilateral spaying) for 9 to 10 days.

f Killed without regard to stage of oestrous cycle.

- Mean index of precision was $0 \cdot 259$.

The results (Table 1) demonstrate that LH levels in rats with lactational and Provera-induced delay periods were lower than in cyclic control rats, but were markedly higher (Table 1) in the bilaterally-spayed progesterone-treated rats. It has already been reported, though not in particular reference to delayed implantation, that suckling (Minaguchi \& Meites, 1967) and Provera administration (Labhsetwar, 1966) block the synthesis of $\mathrm{LH}$ in the pituitary, while progesterone given for the duration of pseudopregnancy beginning on the day of bilateral spaying fails to alter the ovariectomy-induced rise in pituitary LH stores (Labhsetwar, unpublished). The results of the present study are consistent with these findings. The low levels of $\mathrm{LH}$ in the lactational delay period of the rat contrast with the high levels found in the armadillo during delayed implantation (Labhsetwar \& Enders, 1969). 
The author wishes to record his appreciation of the interest and support of Dr A. G. Enders throughout the course of these studies and for his discussion of the manuscript; to Miss Sandra Schlafke for aid in determining the presence of blastocysts. PMSG and HCG were obtained through the courtesy of Dr Jewell of Ayerst Laboratories, while reference standards (FSH and LH) were gifts from the Endocrine Study Section, National Institutes of Health. This study was supported by grant GB-5024 from the National Science Foundation, and grant 5 R01 HD 02613 from the National Institute of Child Health and Human Development.

\section{REFERENCES}

Barnes, A. C. \& Meyer, R. K. (1964) Delayed implantation in intact rats treated with medroxyprogesterone acetate. F. Reprod. Fert. 7, 139.

Bogdanove, E. M. \& GAY, V. (1967) Enhancement of the ovarian ascorbic acid depletion response during estrogen-prolonged pseudopregnancy. An improved bioassay for LH. Endocrinology, 81, 1104 .

Cochrane, R. L. \& Meyer, R. K. (1957) Delayed nidation in the rat induced by progesterone. Proc. Soc. exp. Biol. Med. 96, 115.

Enders, A. C. (1967) The uterus in delayed implantation. In: Cellular Biology of the Uterus, p. 151. Ed. R. M. Wynn. Appleton Century Crofts, New York.

LABHSETWAR, A. P. (1966) Mechanism of action of medroxyprogesterone (17 $\alpha$-acetoxy- $6 \alpha$-methyl progesterone) in the rat. F. Reprod. Fert. 12, 445.

Labhsetwar, A. P. (1969) Age-dependent changes in the pituitary-gonadal relationship. II. A study of pituitary FSH and LH content in the female rat. F. Reprod. Fert. 20, 21.

LABhsetwar, A. P. \& Enders, A. C. (1969) Pituitary LH content during delayed and post-implantation periods in the armadillo (Dasypus novemcinctus). $\mathcal{F}$. Reprod. Fert. 18, 383.

Macdonald, G. J. \& Armstrong, D. T. (1965) Stimulation by LH of estrogen secretion from normal rat corpora lutea actively secreting progesterone. (Abstract). Fedn Proc. Fedn Am. Socs exp. Biol. 24, 321 .

Minaguchi, H. \& Meites, J. (1967) Effects of suckling on hypothalamic LH-releasing factor and prolactin inhibiting factor, and on pituitary LH and prolactin. Endocrinology, 80, 603 .

PARLOw, A.F (1961) Bioassay of pituitary luteinizing hormone by depletion of ovarian ascorbic acid. In: Human Pituitary Gonadotropins, p. 300. Ed. A. Albert. Charles C. Thomas, Springfield, Illinois. 